\title{
Effect of dietary protein level and thyroxine on vitamin A absorption and on plasma proteins in chicks
}

\author{
By I. NIR AND I. ASCARELLI \\ Department of Animal Nutrition and Agricultural Biochemistry, \\ Faculty of Agriculture, Hebrew University, Rehovot, Israel
}

(Received 24 Fune 1966-Accepted 4 October 1966)

\begin{abstract}
I. The effect of dietary protein level and supplementation with thyroxine on the liver storage of vitamin $A$, on the fraction of liver vitamin $A$ in the alcohol form, and on the plasma levels of vitamin $A$ and proteins has been studied in chicks.

2. Liver storage was reduced by lowering the dietary protein level.

3. Protein restriction lowered the percentage of vitamin $A$ found in the liver as retinol.

4. Thyroxine increased both vitamin $A$ storage and the fraction of the total vitamin $A$ as retinol, this effect being dependent on dietary protein level.

5. Plasma vitamin $A$ and plasma protein contents were lowered to a highly significant extent by protein restriction. This drop was essentially caused by reduction of the albumin fraction in chicks fed on a $5 \%$ protein diet and by a reduction of $\beta$ - and $\gamma$-globulins in chicks fed on a Io $\%$ protein diet.

6. Thyroxine supplementation of the diet lowered to a highly significant extent plasma protein content; this reduction was caused by a dramatic fall in the level of plasma albumin. The $\beta$ - and $\gamma$-globulins were concomitantly increased.
\end{abstract}

The interrelationships between dietary protein level, thyroxine and vitamin A metabolism have already been discussed in a previous paper (Nir \& Ascarelli, 1966a). In the work then presented the effects of dietary protein and thyroactive agents on the depletion of liver vitamin A in the chick were studied. The experiments then reported confirmed that in chicks kept on a vitamin A-deficient diet the rate of depletion of liver vitamin A is decreased by a low dietary protein level and increased by supplementation with thyroxine. In all instances the rate of liver depletion was related to the fraction of the total vitamin A present in the liver as free retinol: protein restriction reduced the fraction of liver vitamin $A$ found in the alcohol form and hyperthyroidism increased it. The effect of a low-protein diet on plasma vitamin A and albumin levels and the close correlation between these plasma components were confirmed. It was also concluded, however, that thyroxine caused a highly significant increase of plasma vitamin A though it decreased plasma protein.

Deshmukh, Malathi \& Ganguly (1964) showed that in rats the efficiency of absorption of the vitamin decreased progressively with the lowering of the dietary protein level. These authors gave large doses (ro $\mathrm{mg}$ ) of the vitamin. In the experiments reported now we tested the effect of dietary protein level and thyroxine on liver vitamin $A$ in the chick. In order to explain the contradictory effect of thyroxine on plasma vitamin A and on plasma protein levels further studies were carried out using plasma fractionation. 


\section{EXPERIMENTAL}

\section{Animals and diets}

All chicks were crossbred New Hampshire $\times$ White Leghorn. They were kept in thermostatically controlled, electrically heated batteries equipped with raised wiremesh floors. The experimental feeding period was preceded by a depletion period of 2 weeks during which a commercial basal diet (Table I) almost devoid of vitamin Aactive ingredients $(0.08 \mu \mathrm{g}$ carotene $/ \mathrm{g}$ ) was given. The mean amount of vitamin $\mathrm{A}$ in liver after depletion was ro-30 i.u./liver. During the experimental periods either the basal diet was given (Expts $\mathrm{I}$ and 4 ) or the semi-synthetic diets the compositions of which are given in Table I (Expts 2 and 3). In the diets of thyroxine-treated groups $5 \mu \mathrm{g}$ thyroxine were added per $\mathrm{g}$ diet as a mixture of L-thyroxine in lactose. In all experiments the birds were group-fed.

Table I. Percentage composition of the diets

\begin{tabular}{|c|c|c|c|c|}
\hline \multirow[b]{2}{*}{ Ingredient } & \multirow{2}{*}{$\begin{array}{l}\text { Basal } \\
\text { diet, } \\
\text { Expts I } \\
\text { and } 4\end{array}$} & \multicolumn{3}{|c|}{$\begin{array}{l}\text { Semi-synthetic diets, } \\
\text { Expts 2-3 }\end{array}$} \\
\hline & & $\begin{array}{l}5 \% \\
\text { protein }\end{array}$ & $\begin{array}{l}10 \% \\
\text { protein }\end{array}$ & $\begin{array}{l}30 \% \\
\text { protein }\end{array}$ \\
\hline Sorghum & $64 \cdot 8$ & - & - & - \\
\hline Soya-bean meal $+2 \%$ DL-methionine & $25 \cdot 0$ & $10 \cdot 0$ & $20 \cdot 0$ & $60 \cdot 0$ \\
\hline Soya-bean oil, refined & - & 10.0 & 10.0 & $10 \cdot 0$ \\
\hline Carbohydrate mixture* & - & $7 \times \cdot 0$ & $6 \mathrm{r} \cdot 0$ & $2 I \cdot 0$ \\
\hline Cellulose & - & $3 \cdot 0$ & $3 \cdot 0$ & $3 \cdot 0$ \\
\hline Wheat bran & $4 \cdot 0$ & - & - & - \\
\hline Fish meal & $3 \cdot 0$ & - & - & - \\
\hline Calcium carbonate & $1 \cdot 4$ & - & - & - \\
\hline Dicalcium phosphate & $I \cdot 0$ & - & - & - \\
\hline Salt (fortified) $\dagger^{-}$ & 0.3 & - & - & - \\
\hline Mineral mixture & - & $5 \cdot 9$ & 5.9 & $5 \cdot 9$ \\
\hline Vitamin mixture & $0.4 \dagger$ & O.I & $0.1 \pm$ & $0.1 \ddagger$ \\
\hline Choline chloride & - & 0.15 & 0.15 & 0.15 \\
\hline Antioxidant $\S$ & - & 0.025 & 0.025 & 0.025 \\
\hline Coccidiostat $\|$ & $O \cdot I$ & - & - & - \\
\hline \multicolumn{5}{|c|}{$\begin{array}{l}\text { * Starch } 50 \% \text { and glucose monohydrate } 50 \% \text {. } \\
\uparrow \text { As described by Ascarelli, Budowski, Nir \& Bondi ( } 1964) \text {. } \\
\text { I As described by Nir \& Ascarelli (rg66a). } \\
\S \text { Butyl-hydroxy-toluene; Catalin Corp., New York. } \\
\text { | Bifuran, a product of Dawe-Abic Ltd, Ramat-Gan, Israel, containing } 65 \% \text { nitrofurazone and ro\% } \\
\text { razolidone. }\end{array}$} \\
\hline
\end{tabular}

Expt I. After depletion for 2 weeks chicks were maintained on the basal diet supplemented with 75 i.u. vitamin $\mathrm{A} / \mathrm{I} 00 \mathrm{~g}$ diet. Under these conditions normal growth is achieved but no vitamin A is stored in the liver (Ascarelli \& Bartov, 1963). Chicks were dosed by feeding with a gelatin capsule containing I 460 i.u. stabilized gelatin-coated beadlets of vitamin A palmitate (Chas. Pfizer and Co. Inc., New York). The chicks were dosed at the age of 19,25 or 30 days: the number of chicks per group and time-interval between dosing and killing are given in Table 2. The weight ranges at the different ages overlapped, so that if any correlation was present between bodyweight and vitamin A storage it could be easily found out by individual liver analyses. 
A group of fifty chicks were fed, from the age of 2 weeks to 30 days, on a diet containing $11 \%$ protein. This diet was obtained by diluting the basal diet with a starchglucose monohydrate mixture $I: I$ and adding suitable amounts of vitamins and minerals.

Total vitamin A was determined in all livers. In the chicks killed at 30 days of age the ratio of vitamin A alcohol to ester was also determined. For this determination liver extracts were pooled in samples of six each, so that eight replicates were analysed in each group. Plasma vitamin A was determined in fifteen individual chicks of each group.

Expt 2. This was a $3 \times 2$ factorial experiment in which three levels of dietary protein, namely 5 , Io and $30 \%$, were compared with or without a supplement of thyroxine. Two-week-old chicks were divided into twelve groups of ten chicks each, the mean chick weight being I4I $\mathrm{g}$. All experimental diets were fortified with roo i.u. vitamin $\mathrm{A} / \mathrm{r}$ roo $\mathrm{g}$. In another series of experiments it was found that under these conditions minimal amounts of vitamin A (10-30 i.u.) are stored in the liver while normal growth is achieved. The diets were given for 2 weeks. After this period, 1000 i.u. vitamin A (as water-dispersible vitamin A palmitate; Chas. Pfizer and Co. Inc., New York) were given by mouth in I ml water. The diets were continued for 24 or $48 \mathrm{~h}$ after dosing. The chicks were then bled to death by heart puncture. Vitamin A alcohol and ester were determined in all livers. The vitamin $A$ and protein contents of plasma were determined in all chicks. Electrophoresis of plasma proteins was carried out in fifteen individual chicks from each group.

Expt 3. After depletion for 2 weeks, the chicks were divided into groups of ten, and two replicates were assigned to each treatment. Their mean initial weight was $118 \mathrm{~g}$. The treatments included diets containing $30 \%$ protein, with or without a thyroxine supplement, or $10 \%$ protein. Each diet was given supplemented with four different levels of vitamin A, namely $150,300,600$ and 1200 i.u./roo g. The experimental period was 4 weeks. All groups were pair-fed to the group receiving the $30 \%$ protein diet supplemented with $I 5 \circ$ i.u. vitamin $\mathrm{A} / \mathrm{r} 00 \mathrm{~g}$ and no thyroxine. The chicks were bled to death by heart puncture. All livers were analysed for total vitamin $A$. The ratio of vitamin $\mathrm{A}$ alcohol to ester in the liver was determined in ten individual chicks from each treatment group. Plasma vitamin A and total protein were determined on pooled samples of plasma from five chicks each. Three such replicates were analysed in each treatment.

Expt 4. Vitamin A-depleted chicks were divided into groups of ten each and two replicates were assigned to each treatment. Their mean initial weight was I2I $\mathrm{g}$. They were then given the basal diet supplemented with 300 i.u. vitamin $\mathrm{A} /$ roo g diet, with or without thyroxine supplementation. A thyroxine-treated group was fed ad lib. and another was pair-fed to the group on the unsupplemented diet. The experimental diets were given for 4 weeks, after which the chicks were killed by dislocation of the neck. All livers were analysed for total vitamin $A$, and the fraction of vitamin $A$ in the free form was determined in pooled samples from five chicks each, so that four such replicates were analysed in each treatment.

Analytical methods. The determinations of total liver vitamin A, plasma vitamin A 
and total plasma protein, the plasma protein electrophoresis and the separation of vitamin $\mathrm{A}$ ester and alcohol were carried out as described in our previous paper ( $\mathrm{Nir}$ \& Ascarelli, 1966a).

The results of each experiment were subjected to analysis of variance. Significance among the different treatments was tested by the Studentized range $q$ test (Federer, I955). The terms 'significant' and 'highly significant' indicate statistical significance at the $5 \%$ and I $\%$ level respectively.

\section{RESULTS}

Expt I. The factors that are the subject of the present study, namely protein restriction and thyroxine supplementation, cause an inhibition of growth. This experiment was carried out in order to study the effect of age and body-weight on storage of vitamin A given in a single dose. The results are presented in Table 2. Weight and age, within the fairly narrow limits of this experiment, did not influence storage.

Vitamin A stored in liver $48 \mathrm{~h}$ after dosing was slightly, but not significantly, greater than after $24 \mathrm{~h}$.

Vitamin A stored in liver, the fraction of liver vitamin A in the alcohol form, and protein and vitamin $A$ levels in plasma were all reduced to a highly significant extent by the low-protein diet.

Expt 2. The results are presented in Tables 3, 4 and 5. In addition to the obvious effect of dietary protein level on growth, it may be seen that thyroxine decreased bodyweight on low-protein diets. Such a synergistic effect between thyroxine and low dietary protein has been observed in other experiments.

The total vitamin A stored was less on the low-protein diet but increased with thyroxine (Table 5). The thyroxine had no effect on the vitamin A storage on the $30 \%$ diet (Table 3): here again the effect of thyroxine was most marked under conditions of protein deficiency. The vitamin A ester content of liver increased by a slight but highly significant extent when the protein content of the diet was lowered. Thyroxine also caused a significant increase in this fraction on low-protein diets only.

The vitamin A alcohol content of liver decreased with the lowering of the dietary protein level but increased with thyroxine supplementation, both these effects being statistically significant.

The fraction of vitamin $\mathrm{A}$ in the livers in the alcohol form was very much influenced by the protein level of the diet. Thyroxine also caused a statistically significant rise, and again its effect was most marked at the lowest dietary protein level.

The forms of the vitamin $\mathrm{A}$ in the liver did not reach an equilibrium $24 \mathrm{~h}$ after dosing: whereas no change occurred in the total liver stores between 24 and $48 \mathrm{~h}$ after dosing, a highly significant rise occurred during this period in the fraction of vitamin $\mathrm{A}$ in the alcohol form, the increase being of the order of $30 \%$.

Lowering of dietary protein reduced the level of plasma vitamin A, each protein level differing from the others to a highly significant extent. Thyroxine slightly increased plasma vitamin A level when the $10 \%$ protein diet was given but had no effect when the lower or higher levels were given. In the non-supplemented groups vitamin 
Vol. 2I

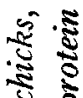

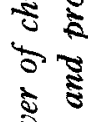

空

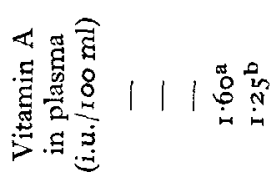

胥

.5

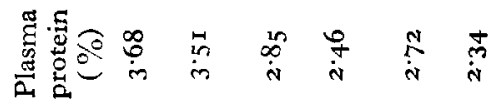

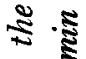

.$\Sigma$

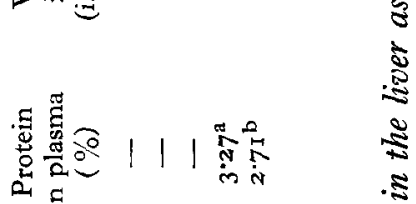

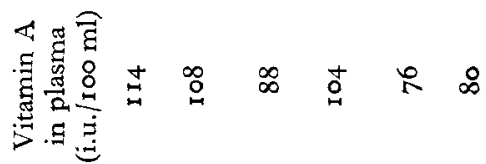

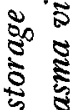

$\pi \frac{1}{2}$

.

(

这

8

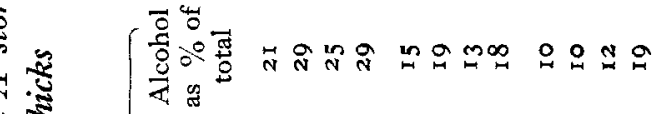

เ

I

.

के

过

竎

So ะँ

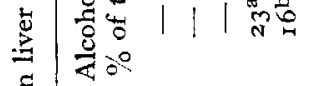

.

露

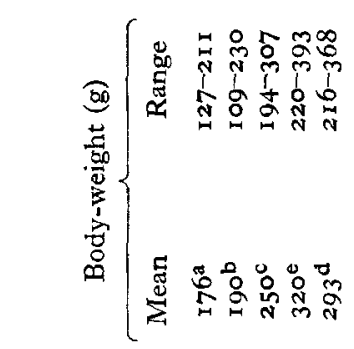

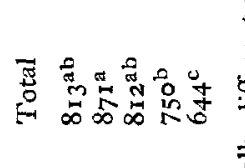

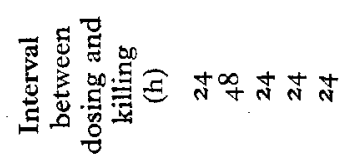

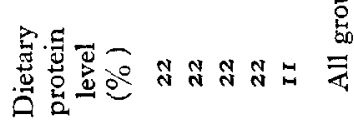

$\nabla$ च

तั

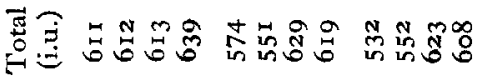

ษ.

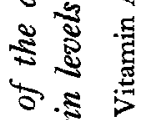

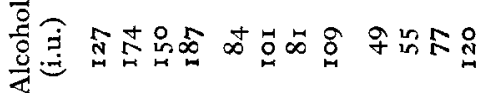

:

เป็

क्षे

है

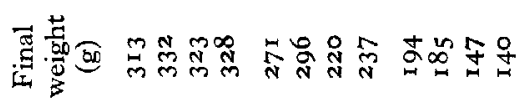

䓀

$\approx$

ब.

$\stackrel{2}{3}$

ค.

हิ

$\frac{2}{6}$

$\ddot{z} \cdot \Xi$

这京

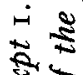

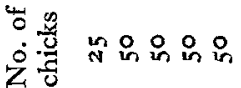

芯

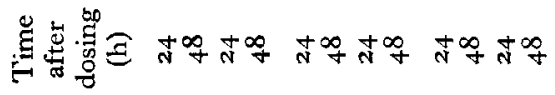

赵

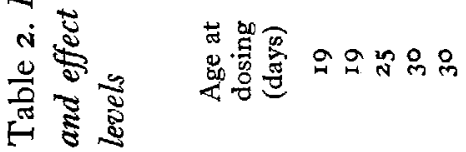

तं

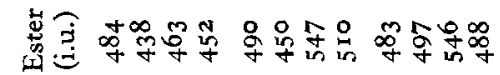

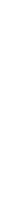




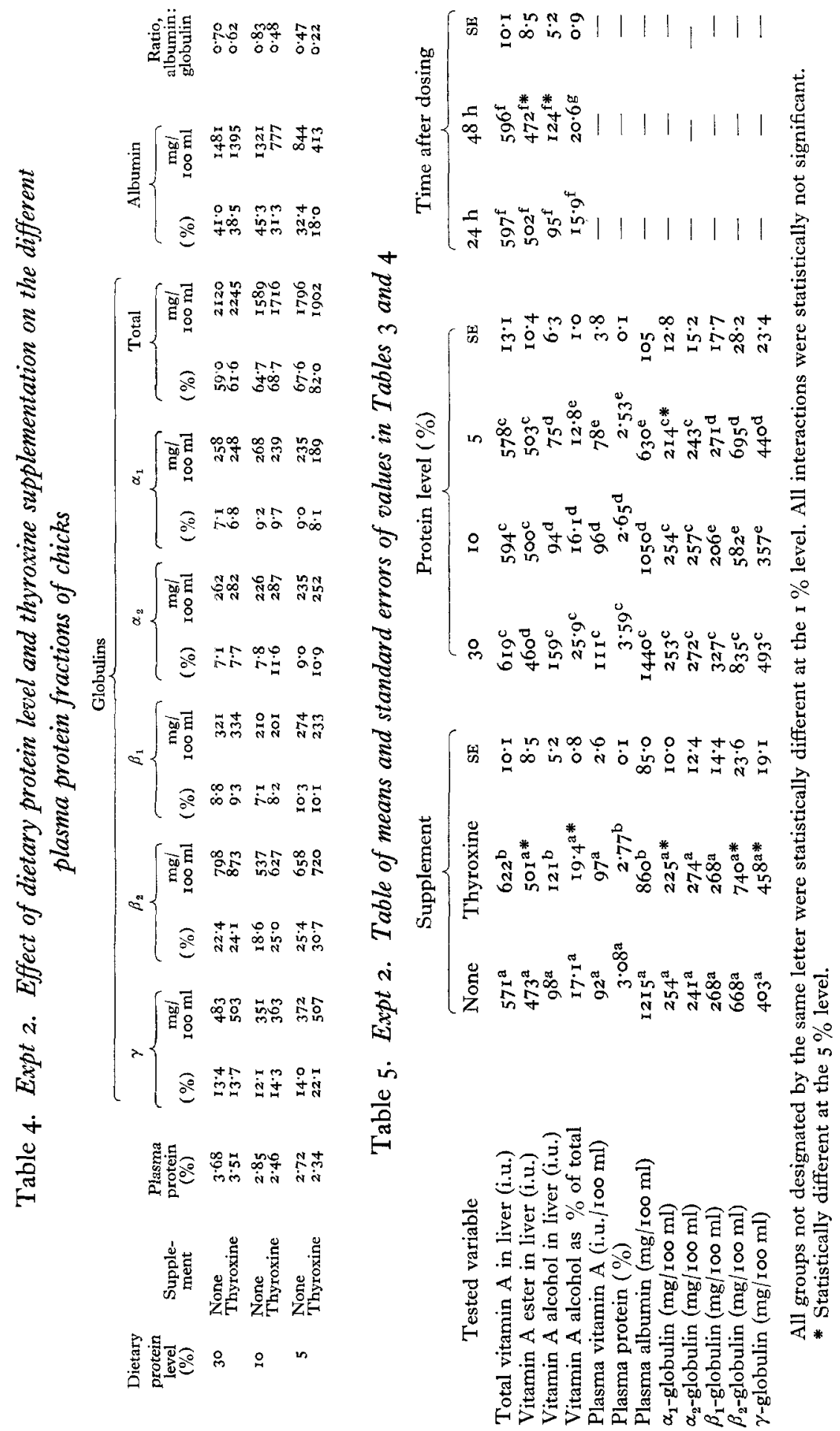


A level in plasma was related to a highly significant extent to plasma albumin content (Fig. $\mathrm{x}$ ). No such relation was found when thyroxine was added to the diets. Also no correlation was found between the $\alpha_{1}$-globulin and the plasma vitamin A levels.

Plasma protein was decreased to a highly significant extent by both protein restriction and thyroxine. In the unsupplemented groups this decrease was caused essentially by the dramatic reduction of albumin with the $5 \%$ protein diet, and by the decrease in total globulin with the $10 \%$ protein.

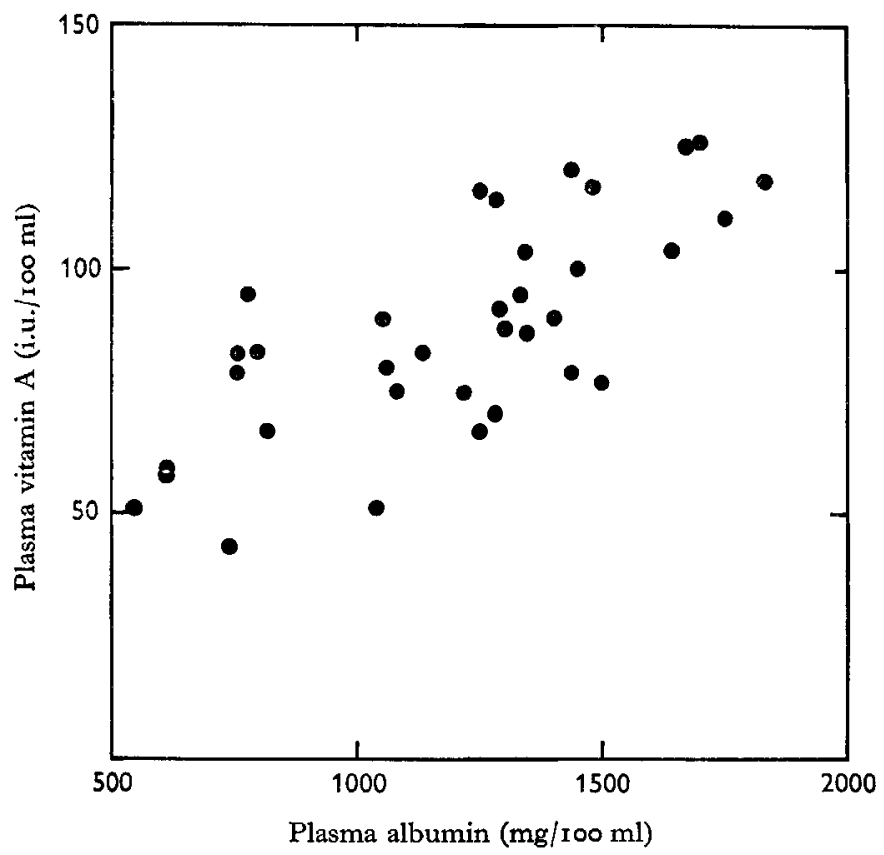

Fig. I. Expt 2. Scatter diagram showing the relation between the plasma levels of vitamin $A$ and albumin in chicks without thyroxine supplement.

The following changes were observed in the absolute values of the different protein fractions: the lowering of the protein level decreased plasma albumin, each level being statistically different from the other two. The $\alpha_{1}$-globulin was significantly lower only with the $5 \%$ protein diet. Protein restriction had no influence on the $\alpha_{2}$-globulin, but reduced the $\beta_{1^{-}}, \beta_{2^{-}}$and $\gamma$-globulins: the levels of these three proteins differed to a highly significant extent on each diet, but the levels on the $10 \%$ protein treatment were lower than on the $5 \%$ treatment (Table 5).

At all protein levels thyroxine lowered the albumin and $\alpha_{1}$-globulin and increased the $\beta_{2^{-}}$and $\gamma$-globulins.

The effect of the treatments on the electrophoretic picture of the plasma proteins is summarized in Fig. 2. The values obtained by densitometry for the different fractions of the individual fractions of the individual electrophoretic strips were calculated as percentage of the total protein content, and from them the curves were derived by averaging the relative values obtained. It can be seen that the relative amounts of the 
albumin were generally decreased by the lowering of dietary protein level, whereas the slow migrating proteins were increased. At all protein levels thyroxine decreased the albumin percentage and increased that of the slow migrating globulins.

Expt 3. The results are presented in Table 6. Protein restriction and thyroxine decreased body-weight and increased the ratio of food eaten to weight gained $(F / G)$. Vitamin A level in the diet had no significant effect on body-weight or $F / G$.

Protein restriction decreased vitamin A storage in the liver at all dietary levels of the vitamin. In contrast to our previous findings (Ascarelli, Budowski, Nir \& Bondi, I964) also thyroxine decreased vitamin A liver storage at all dietary levels of the vitamin. Doubling the vitamin A level in the mash doubled the percentage of dietary vitamin A stored in the liver on all treatments when the dietary level was increased from 150 to 300 i.u./100 $\mathrm{g}$ mash. In the chicks fed on the $30 \%$ protein diet the percentage of dietary vitamin A stored again doubled when the intake was raised to 600 i.u./ $100 \mathrm{~g}$ mash.

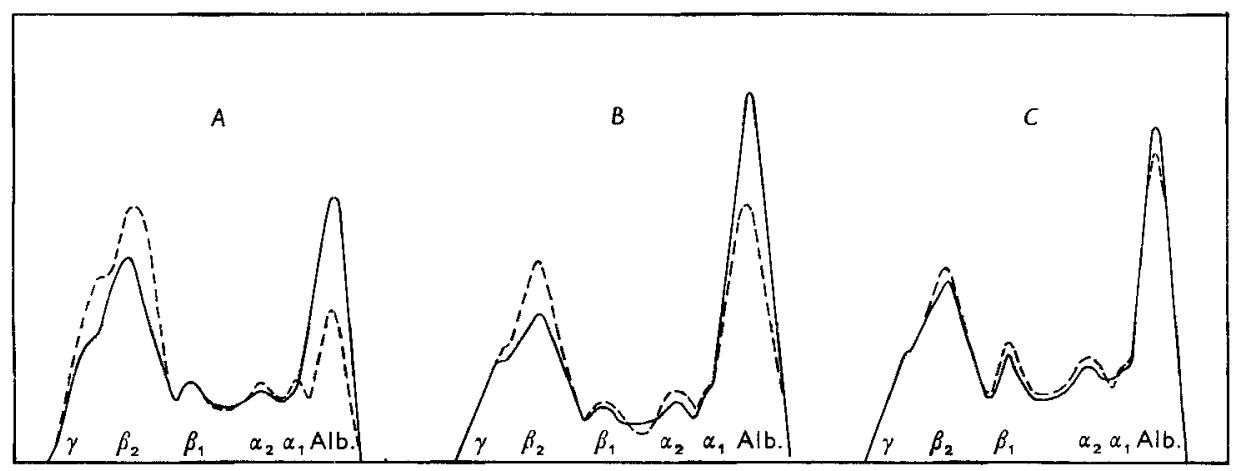

Fig. 2. Expt 2. Electrophoretic picture of the plasma protein of chicks given a diet with (A) $5 \%$, (B) $10 \%$ or $(C) 30 \%$ protein with or without thyroxine supplement. Each curve represents the mean value for fifteen individual analyses. - , without supplement; --- , with thyroxine supplement. The labelled peaks correspond to the fractions listed in Table 4 .

The fraction of vitamin $A$ in the liver in the alcohol form decreased with protein malnutrition and increased to very high levels (up to $59 \%$ ) in the chicks on thyroxinesupplemented diets.

When the liver vitamin $\mathrm{A}$ of each chick is expressed as a percentage of the maximum storage obtained in each group and the calculated values are plotted against the chicks' body-weight, a clear correlation can be seen in the chicks fed on the unsupplemented diets (Figs. $3 A, B$ ). No such correlation was found in the thyroxine-treated chicks (Fig. $3 C$ ).

A low protein level and thyroxine supplementation decreased vitamin A level in plasma. In the chicks fed on a $30 \%$ protein diet, both with and without thyroxine, vitamin $A$ in plasma reached a peak at the $600 \mathrm{i} . \mathrm{u} . / 100 \mathrm{~g}$ level, and in the chicks fed at the low protein level the plasma vitamin A content increased further when the dietary vitamin A was raised to I200 i.u./roo g.

Plasma protein was decreased as usual by the low-protein and thyroxine treatments. 
Vol. 2I

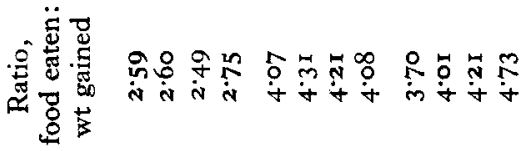

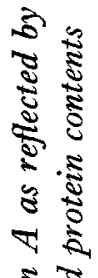

.

i.

$\cdot \frac{2}{2}$

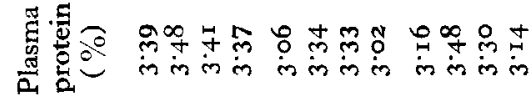

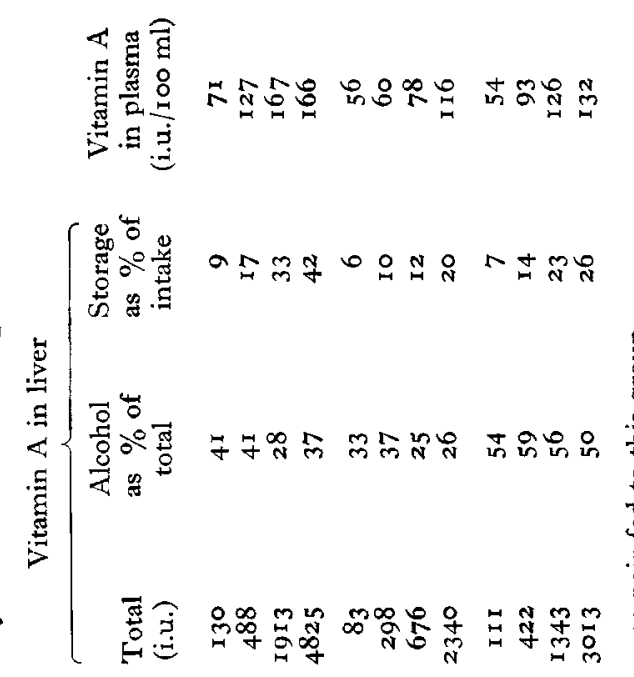

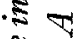

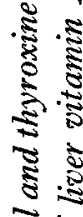

कू पू

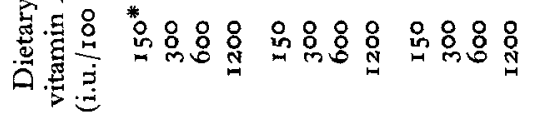

这

$\dot{n} \overline{4}$

然.

施

竞

\{

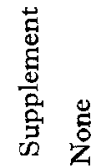

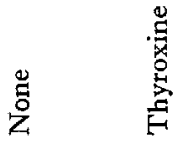

尊题

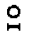

$\stackrel{\circ}{n}$ 
Expt 4. The inhibitory effect of thyroxine supplementation on vitamin A storage found in the previous experiment could have been caused by the superimposed stress which the restricted feeding caused to the thyroxine-treated chicks. In order to check this hypothesis, Expt 4 was carried out and its results are shown in Table 7. When thyroxine-treated chicks were pair-fed to the control group growth was reduced,

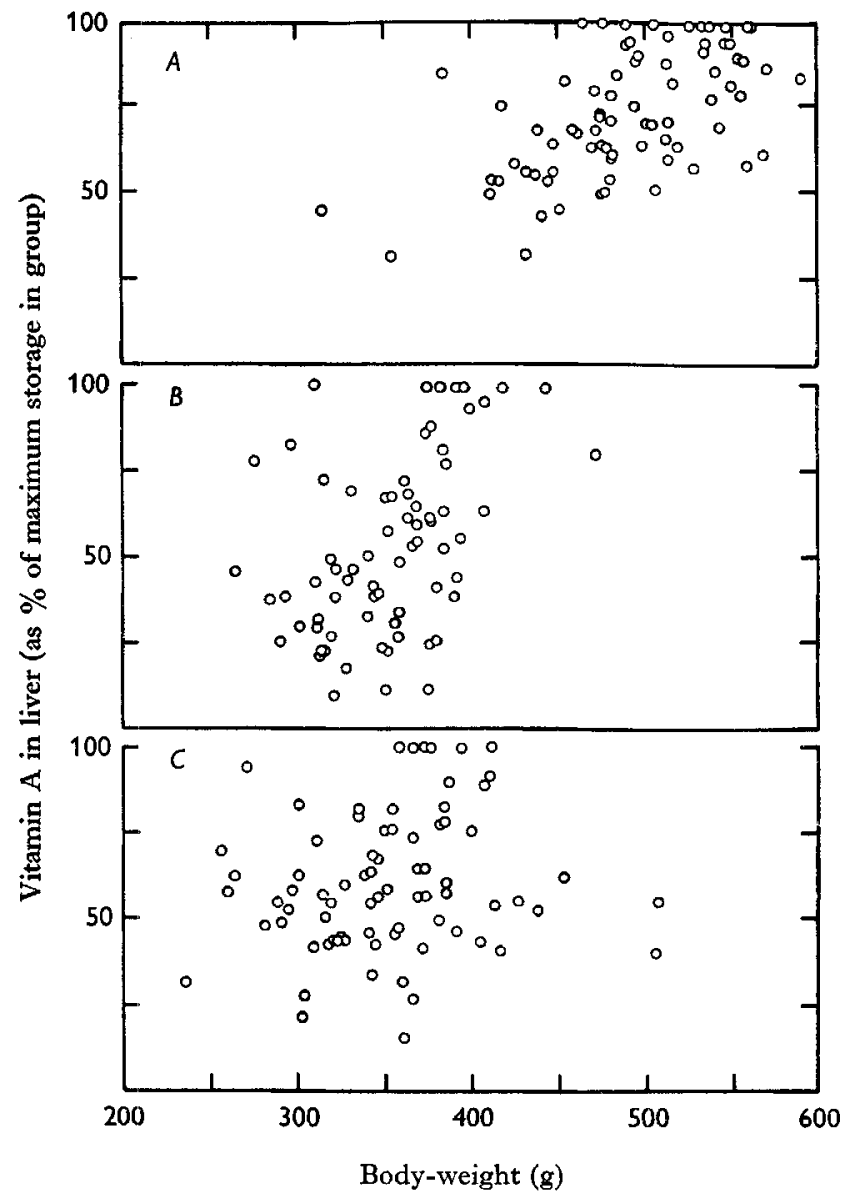

Fig. 3. Expt 3. Scatter diagram showing the relation in chicks between body-weight and liver vitamin $A$ (expressed as a percentage of maximum storage in each group) on $(A)$ a $30 \%$ protein diet, $(B)$ a $10 \%$ protein diet, or $(C)$ a $30 \%$ protein diet supplemented with thyroxine.

whereas on $a d$ lib. feeding even thyroxine-treated chicks achieved the same growth as the control group. Liver vitamin A was increased by thyroxine in either the pair-fed chicks or those fed $a d$ lib. Thyroxine increased the fraction of vitamin A in the liver in the alcohol form. As in the previous experiment, a correlation was found between body-weight and total liver vitamin $A$. This correlation was confounded by the effect or the different treatments when all results were considered together, but it was clearly seen when each treatment was considered by itself. 
Table 7. Expt 4. Effect of thyroxine in the diet and restricted feeding of chicks on vitamin $A$ level and percentage of vitamin $A$ in the liver

\begin{tabular}{|c|c|c|c|c|c|}
\hline \multirow[b]{2}{*}{ Treatment } & \multirow[b]{2}{*}{$\begin{array}{c}\text { Final } \\
\text { body- } \\
\text { weight } \\
(\mathrm{g})\end{array}$} & \multicolumn{3}{|c|}{ Vitamin $A$ in liver } & \multirow[b]{2}{*}{$\begin{array}{c}\text { Ratio, } \\
\text { food } \\
\text { eaten: } \\
\text { wt } \\
\text { gained }\end{array}$} \\
\hline & & $\begin{array}{l}\text { Total } \\
\text { (i.u.) }\end{array}$ & $\begin{array}{c}\text { Alcohol } \\
\text { as } \\
\% \text { of } \\
\text { total }\end{array}$ & $\begin{array}{c}\text { Storage } \\
\text { as } \\
\% \text { of } \\
\text { intake }\end{array}$ & \\
\hline Control & $467^{\mathrm{a}}$ & $389^{a}$ & $42^{\mathrm{a}}$ & I6 & $2 \cdot 35$ \\
\hline $\begin{array}{l}\text { Thyroxine supplement, pair-fed to } \\
\text { control }\end{array}$ & $410^{\mathrm{b}}$ & $489^{a b}$ & $44^{\mathrm{a}}$ & 20 & $2 \cdot 85$ \\
\hline Thyroxine supplement, ad lib. feeding & $473^{\mathrm{a}}$ & $619^{\mathrm{b}}$ & $54^{\mathrm{b}}$ & 22 & $2 \cdot 67$ \\
\hline
\end{tabular}

All groups not designated by the same letter were statistically different at the I $\%$ level.

\section{DISCUSSION}

Most studies on the effect of protein restriction on vitamin A absorption have been made on rats and fall into two groups: ( $\mathrm{I}$ ) rats were maintained on diets of varying protein content and daily supplements of small amounts of vitamin A (Basu \& De, 194I; Baumann, Foster \& Moore, 1942; Jagannathan \& Patwardhan, 1960; Esh, Bhattacharya \& Som, 1960); (2) rats previously maintained on different protein levels were given a single massive dose of vitamin A, following which their liver storage was studied at short time-intervals (Deshmukh et al. 1964). The general conclusion from both types of experiment was that a low-protein diet decreases vitamin A storage. In all these experiments the influence of decreased body-weight resulting from protein restriction was disregarded. Our results with chicks show that body-weight, within the range used (127-393 g), did not influence storage when a moderate amount of vitamin A was given in a single dose. However, this may not be true with massive doses of the vitamin, in which event body or liver size may become a limiting factor. There was possibly a slight tendency for lower storage in the bigger chicks. As this trend is opposite to the effect of protein level on vitamin A storage it is unlikely that a bias could be introduced by weight differences in our studies on the influence of protein restriction on vitamin A storage.

Protein restriction lowered only slightly the storage capacity of the chicks' liver for a single moderate dose, the lowering being caused by a decreased storage of the vitamin in its alcohol form. When vitamin A was added to the diet during a 4-week period, the influence of dietary protein level on storage was very marked at all levels of vitamin A supplementation. This difference in storage is even greater if we account for the decreased utilization of liver reserves by the chicks given the low-protein diet (Nir \& Ascarelli, 1966a). Two explanations may be given for these apparently contrasting results: (I) a 2-week period of protein restriction may not have been long enough to damage the physiological mechanism through which vitamin $A$ is stored in the liver. As the feed, and consequently also the vitamin A intake, is much greater during the $5^{\text {th }}$ and 6th weeks of the chick's life than during the $3^{\text {rd }}$ and $4^{\text {th }}$ weeks, the effect of protein restriction could become more marked in the longer experiment, as most of the vitamin was ingested when the storage mechanism was most affected; 
(2) the mechanism of absorption of vitamin A dispersed in water and given in a single dose may be somewhat different from that of vitamin A mixed in the diet. As a whole, the experiments here reported confirm that the amount of vitamin A stored in the liver is affected by the level of dietary protein.

Thyroxine and higher dietary protein levels increased the free retinol in liver, both in absolute amount and as a percentage of total vitamin A. These results are in accordance with our previous studies on the influence of these factors on vitamin $A$ utilization from liver reserves (Nir \& Ascarelli, r966a). Deshmukh et al. (1964) have shown that, after an oral dose of vitamin A acetate, the amount of retinol found in the intestinal contents of rats kept on a low-protein diet was significantly lower than the amount found in rats kept on a higher protein level. In vitro experiments by the same authors showed that homogenates of pancreas and intestinal mucosa of rats raised on a low-protein diet had reduced enzymic activities for synthesis and hydrolysis of vitamin $A$ esters. In what measure, if at all, the enzymic activities of the pancreas and other tissues influence the vitamin $\mathrm{A}$ alcohol level in the liver remains to be elucidated.

The very high levels of vitamin A alcohol, found in the livers in the experiments in which vitamin A was given in the diet, were probably due to temperature, these experiments being conducted in the hotter summer period when the mean of maximum daily temperatures was $3 \mathrm{I}^{\circ}$ : a correlation between environmental temperature and the fraction of vitamin A in the liver as retinol has been shown (Nir \& Ascarelli, I $966 b$ ); that this high ratio of retinol is related to the higher vitamin A requirement in a hot climate has not been proved, but such a probability may be assumed.

Vitamin A level in plasma was related to a highly significant extent to plasma albumin, whose level depends on dietary protein level. No relation was found between the $\alpha_{1}$-globulin and vitamin A contents of plasma. This finding is in accordance with the results of our previous studies (Nir \& Ascarelli, I966a). These relationships suggest that vitamin A alcohol is bound to plasma albumin or to another protein migrating in the electrophoretic field with plasma albumin.

Plasma proteins. Protein restriction lowered the levels of most plasma proteins; however, the chicks fed on the diet containing $5 \%$ protein had higher levels of $\beta_{1^{-}}$ $\beta_{2^{-}}$and $\gamma$-globulins than the chicks fed on the 10\% protein diet. According to Miller, Hanavan, Titthasiri \& Chowdhury (1964), who studied plasma protein synthesis using a technique of isolated liver perfusion, virtually all plasma proteins are synthesized in the liver: extrahepatic tissues are primarily concerned with the production of $\gamma$ globulins and of $\beta$-globulins generically related to the $\gamma$-globulins. Our results therefore show that giving a $5 \%$ protein diet or adding a thyroxine supplement causes an increase of the plasma proteins which may be synthesized in extrahepatic tissues. Little work has been done on the influence of thyroid status on plasma or serum proteins and none of it has been with chicks. In man, Slavnov (1962) showed that in thyrotoxic patients total serum protein levels were normal, but that this normal level resulted from a lowered albumin and elevated $\gamma$-globulins. Also in man, Duric, Micié $\&$ Simić (1963) showed that in hyperthyroidism $\alpha$ - and $\beta$-lipoproteins were lowered but neutral fat was increased in the serum. In rats, Stas, Grabski \& Masny (1962) and Kekki (1964) showed that thyroxine has only a slight effect in reducing levels of 
total serum protein: the albumin fraction was not affected, $\alpha_{1}$-globulin was decreased and all the other globulins were increased. Total serum protein increases with the feeding of oestrogen, but is inhibited by thyroxine (Sturkie, 195I). In our experiments with chicks, thyroxine had a decreasing effect on total plasma protein, the reduction being caused essentially by a decrease of the albumin and a slight decrease of the $\alpha_{1}$-globulin; $\alpha_{2}$-globulin and $\beta_{1}$-globulins were not affected and all the other globulins were increased. An interesting observation was made by Kekki (1964), namely that in his thyroxine-treated rats the level of albumin was unchanged, but its turnover was greatly accelerated, i.e. both the catabolism and the synthesis of this fraction were increased. This observation can explain our finding that the decrease of the albumin fraction was small in the chicks given an optimal level of protein, but of dramatic proportions in the chicks given the low-protein diets: apparently under these conditions the losses through increased catabolism could not be made good by increased synthesis.

It was shown in rats (Garbers, Gillman \& Peisach, 1960) and in man (Krinsky, Cornwell \& Oncley, I958; Glover \& Walker, I964) that vitamin A ester is transported in blood in combination with low-density lipoproteins. These proteins migrate in the electrophoretic field with $\beta$-globulins. It is noteworthy to point out a parallelism between the levels of the $\beta_{2}$-globulins and of liver vitamin $A$ ester under the influence of thyroxine supplementation, both levels being increased to a significant extent. It may well be that, when a thyroxine supplement was given, a better transport of vitamin A ester was achieved by the higher concentration of low-density lipoproteins in plasma, which presumably was associated with the higher concentration of $\beta$ - and $\gamma$-globulins. Only very small amounts of vitamin A ester remained in plasma $24 \mathrm{~h}$ after dosing; therefore we could not determine if there is a correlation between the levels of $\beta$ globulins and vitamin A ester in plasma.

When vitamin $A$ was given in a single dose to chicks fed during 2 weeks on diets containing different protein levels, thyroxine improved storage only in the chicks given the 5 and $10 \%$ protein levels. With a high level of dietary protein there was no such effect.

As we have already pointed out, thyroxine, administered at the usual level of $5 \mu \mathrm{g} / \mathrm{g}$ mash, had unexpected effects in Expt 3: body-weight, amount of vitamin A stored in the liver and the fraction of vitamin A stored were all decreased. The influence of thyroxine was apparently so strong that it confounded the correlation between body-weight and liver storage, which was found in the unsupplemented groups of Expt 3 and in all the groups of Expt 4. That these effects were not caused by the superimposed stress of feed restriction was ruled out by the results of Expt 4 . Another tentative explanation could be an influence of the high energy level of the semi-synthetic diet used in Expt 3. However, in another experiment, carried out in relation to a different project, chicks were fed on this diet supplemented with the same level of thyroxine, and its results showed no interaction between thyroxine supplementation and a high-energy diet of this type. We are of the opinion that the particular climatic conditions prevalent while the experiment was carried out (maximum temperatures up to $34^{\circ}$ and many days of low relative humidity) imposed a very 
intense stress on the thyroxine-treated chicks. Thyroxine production being lower in summer (i.e. during hot weather) than in winter, it is possible that the thyroxine was physiologically more potent under the climatic conditions prevalent in Expt 3 and could possibly reach a harmful range: as we have already shown in previous work (Ascarelli et al. 1964), a level of $5 \mu \mathrm{g}$ L-thyroxine/g diet increased vitamin A storage with no effect on body-weight, and to $\mu \mathrm{g}$ thyroxine/g depressed body-weight and caused a less efficient storage of vitamin A. The effect of a low level of thyroxine in increasing the liver storage of vitamin $A$ in chicks is emphasized if we take into account the increase in vitamin A utilization caused by the thyroxine (Nir \& Ascarelli, I966a).

The authors wish to thank Chas. Pfizer and Co. Inc., New York, for a gift of waterdispersible vitamin A palmitate.

This work was financed by grant no. FG-Is-I35 from the US Department of Agriculture.

\section{REFERENCES}

Ascarelli, I. \& Bartov, I. (1963). Poult. Sci. 42, 232.

Ascarelli, I., Budowski, P., Nir, I. \& Bondi, A. (1964). Poult. Sci. 43, 370.

Basu, N. M. \& De, N. K. (194I). Sci. Cult. 6, 672.

Baumann, C. A., Foster, E. G. \& Moore, P. R. (1942). F. biol. Chem. 142, 597.

Deshmukh, D. S., Malathi, P. \& Ganguly, J. (r964). Biochem. F. 90, 98.

Durie, D. S., Micie, J. V. \& Simic, N. (1963). Acta med. iugosl. 27, 37.

Esh, G. C., Bhattacharya, S. \& Som, J. M. (1960). Ann. Biochem. exp. Med. 20, I5.

Federer, W. T. (1955). Experimental Design. New York: MacMillan.

Garbers, C. F., Gillman, J. \& Peisach, M. (1960). Biochem. F. 75, 124.

Glover, J. \& Walker, R. J. (1964). Exp. Eye Res. 3, 327.

Jagannathan, S. N. \& Patwardhan, V. N. (1960). Indian $\mathcal{~}$. med. Res. 48, 785.

Kekki, M. (1964). Acta Endocr. Helsinki 46, Suppl. 9 г.

Krinsky, N. 1., Cornwell, D. G. \& Oncley, J. L. (1958). Archs Biochem. Biophys. 73, 233.

Miller, L. L., Hanavan, H. R., Titthasiri, N. \& Chowdhury, A. (1964). Adv. Chem. Ser. 44, I7.

Nir, I. \& Ascarelli, I. (1966a). Br. F. Nutr. 20, 4r.

Nir, I. \& Ascarelli, I. (1966 b). Br. Poult. Sci. 7, 297.

Slavnov, V. N. (1962). Vopr. Sovrem Khirurgii Sb. p. 104. Quoted in Chem. Abstr. (1964), 60, 12338.

Stas, J., Grabski, J. \& Masny, N. (1962). Endokr. pol. 13, 433.

Sturkie, P. D. (1951). Endocrinology 49, 565. 